Jelena Božović1, Ivan Božović1, Isidora Ljumović ${ }^{2}$ 1 University of Pristina temporarily seated in Kosovska Mitrovica, Faculty of Economics, Kosovska Mitrovica, Serbia 2Institute of Economic Sciences, Belgrade, Serbia

\title{
Impact of HRM Practices on Job Satisfaction of Employees in Serbian Banking Sector
}

DOI: 10.7595/management.fon.2018.0035

\begin{abstract}
:
Research Question: The study aims to identify the level of effectiveness in Human Resource Management (HRM) and its impact on employees' satisfaction in the banking sector of Serbia. Motivation:The aim of this research is to measure the satisfaction of employees in the banking sector of Serbia. In addition to the overall goal of this study, it is necessary to list some specific objectives: to provide human resource management (HRM) analysis, to focus on the main dimensions of HRM in practice, to present a test for measuring employee satisfaction in practice, to identify weaknesses in management that affect employee satisfaction and to propose measures to improve employee satisfaction and increase motivation. The research attempts to point out the basic driving factors for better work and effects, as common motives for all workers, such as salary, job interest, the opportunity of further progress, the degree of autonomy in the performance of tasks, and the possibility of personal affirmation. The challenge that puts the management of human resources and its application into practice becomes a very relevant field of inquiry. It is important to know the answer to the research question in order to arrive at a response to whether or not to comply with Pareto optimum: "When we know where and why we are headed, little things can point us to the right direction" (Debreu, 1954). The novelty in the study is that some aspects (career improvement and job security) bring employees a greater degree of satisfaction, while others (salary and business climate) are rated as bringing significantly lower levels of satisfaction. The work is based on the applied Kruger study (Kruger et al., 2008). It is used for research, because in this specific case it makes it possible to collect the results of mortgage execution on a sample of employees of 10 banks, whose results would be useful at the level of the banking sector in Serbia. Idea: The basic idea of this paper is to evaluate different levels of employee satisfaction with different dimensions of quality of work in banking institutions. The study involves analyzing the level of satisfaction from the aspect of selection and selection of employees, job security, employee salaries, career advancement, professional training and professional development, management style, job responsibilities, awards and recognitions and, finally, business climate as key dependent variables. The key independent variables are gender, age, education and length of service, as demographic characteristics of the respondents. Data: The analysis was carried out through a questionnaire sent to the employees of the bank. The target population is employed in the banking sector on the territory of Serbia. Among the different banks, this study takes into account ten banks. 93 questionnaires were available for statistical analysis. Tools: Statistical analysis of all collected data (Z-test, correlation analysis) were used to draw conclusions about relationships between variables, specifically what employees start in the organization. With the help of the Pierson correlation coefficient, statistical significance is determined, which shows motivational effects in the behavior of employees. Findings: The findings revealed a high level of effectiveness of all HRM practices. A strong positive relationship has been identified between the effectiveness of HRM and employees' satisfaction. The study recommended improving financial compensation system of banks, which would positively increase the level of employees' satisfaction. Contribution: This paper expands the existing research related to the developing employee motivation in the banking sector and formulates practical suggestions for increasing motivation and avoiding its relativization. Promoting transparency and publicity and an effective system of rewards, compensation and salaries according to merit and contribution to work tasks should be promoted. It is possible to achieve a business climate by respecting the individuality and dignity of each employee, and thus to build trust among employees and loyalty to the institution.
\end{abstract}

Keywords: human resources management, banking sector, motivation, business climate, professional training

JEL classification: M21, M14, O15.

\section{Introduction}

As one of the most important phenomena for the country's economy employment is important from various aspects. It is a way to earn income and provide for living, it enhances socializing, creates and increases self-confidence, morale integrity, enables independence, increases ability to enhance and develop skills, 
competences and knowledge and contributes to the society and public finances. A low level of employment and/or salary boosts migrations towards those areas that offer employment under better conditions, such as employment in the financial sector that is traditionally recognized as one with the highest salaries.

According to the latest data from the Statistical Office of the Republic of Serbia, the unemployment rate was $12.3 \%$ at the end of the second quartile of 2017. Turning these percentages in to a number, there were more than 384 thousands of unemployed in Serbia at the end of the second quartile of 2017. There are estimates that more than 60,000 persons do not receive a salary or any kind of payment for their work. The problem of black market economy is huge and a number of employees receive only a part of their salary through legal channels, where the employer pays taxes and contributions only to a proportion, not to the full amount of salary. Research from the Project "Needs of the labour market and the position of young unemployed" provides an insight into the needs of the employers in the financial services industry. According to the survey conducted as one of the project activities, only $38 \%$ of employers organize professional practice, but every third young person sees this practice as a chance for better positioning in the labour market. The majority of employers (54\%) that participated in this research stated that they do not plan to hire new employees. Employers also tried to identify problems with employing youth persons.

Macro- (rising unemployment, structural unemployment, rising cost of living) and microeconomic aspects (hiring freezes, low salaries, layoffs) affect employees in Serbia in a negative way, increasing the disincentive of employees, fear, uncertainty and stress. In such circumstances, there is an important question: "How to motivate employees"? Do we need to comply with Pareto optimum: "When we know where and why we are headed, little things can point us to the right direction". Or we do not see any sense in this, there is no need for motivation, because employees experience a high level of fear for their job (Kilenthong \& Townsend, 2011).

In the countries with major structural reforms, initially, there is a relatively dynamic growth in all sectors, especially the financial sector, including the banking system. Such dynamic growth is usually followed by an increase in capacity including the number of employees. The Serbian banking sector has gone through significant changes since 2000, with two major characteristics: ownership transformation and consolidation. Owner transformation was manifested primarily as significant changes in the ownership structure of banks, increased private sector participation (primarily foreign investors) and changes in the number and relative importance of banks. There are numerous research works that confirm the fact that the ownership structure in the banking sector of the countries that went through the process of transformation, significantly changed in favour of banks with domicile foreign capital (for details see: Claessens \& van Horen, 2008; Degryse et al., 2012; Detragiache, Tressel \& Gupta, 2008; Beck \& Peria 2010). The share of foreign ownership in the banking systems of the countries that joined the European Union significantly exceeded half of the total banking sector, while the banking sector of Serbia, by the origin of ownership, is a typical representative of a group of countries related by historical heritage and geo-political characteristics (Marinkovic, Ljumovic \& Zivkovic, 2011). Another very important feature of the internationalization process is the consolidation of banks. In the period after 2000, 68 banks disappeared and to this day their number is constantly decreasing. During 2001, a large number of banks were liquidated, among them the four largest state banks (Jugobanka, Investbanka, Beobanka and Beogradska banka), at that moment employing $36.5 \%$ of workforce in the banking sector. A large-scale liquidation of the banks decreased the number of employees in the banking sector for more than 8,000 at the moment they were liquidated. On the other hand, entry of new banks had a highly positive effect on the growth of employment, reducing the effect of large-scale restructuring of the banking sector since 2000. The period after the structural reforms in the banking sector led to an evident increase in the number of employees per year, where the most dynamic growth took place in the early years of banking sector internationalization. This process had a strong positive impact to the growth of employment during the first years. However, during the financial crisis certain negative effects were manifested and since 2009 there has been a constant decrease in the number of employees in the banking sector of Serbia (Figure 1). The economic crisis in general, and especially the global financial crises (2007 and the present one) led to bankruptcy, and thus to a loss of funds of many businesses and individuals. Large companies create frameworks that use social and human values as decision-making criteria (Kanter, 2011). 


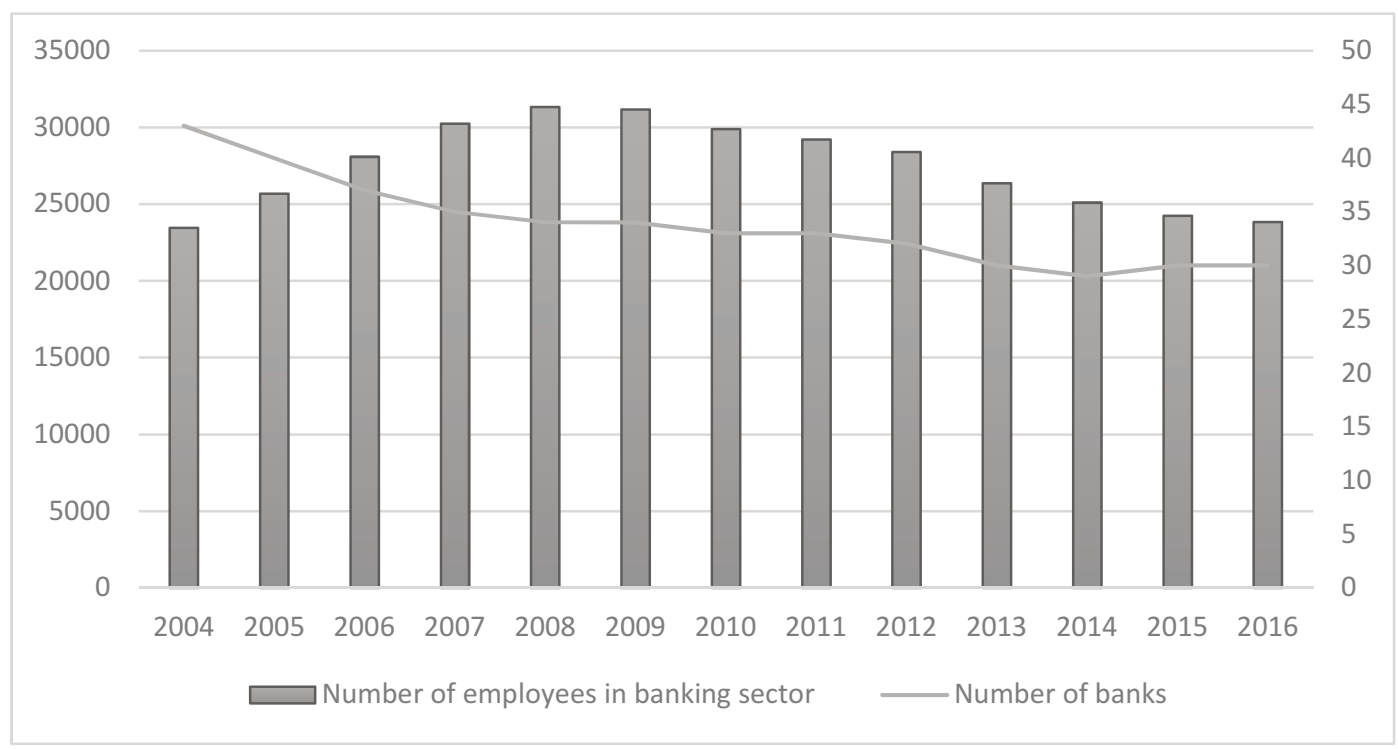

Figure 1: Number of employees in the banking sector and the number of banks 2004-2016 Source: Annual Reports from National Bank of Serbia 2004-2016

The aim of this paper is to measure the satisfaction of employees in the banking sector in Serbia. Our main goal was to provide an overview and analysis of human resource practices that focuses on the main dimensions of HRM, to propose a test to measure employee satisfaction in practice, to detect weaknesses in the management that affect employee satisfaction and to propose measures to improve employee satisfaction and increased motivation. These activities are all linked by a concern for employee well-being and ensuring organization treats employees in a way that provides mutual benefit for both the employee and the organization.

\section{Literature Review}

Management of human resources is a hot topic as an expression of the necessity arising from the group lifestyle and work. More than ever, relationships in the group are constantly changing and improving over time. Along with these changes the process of managing people is evolving over time. It started with Robert Owen and an experiment in his own factory, throughout Industrial Revolution and finally is developing with the current global technological revolution. The relations of superiority and inferiority observed for thousands of years, slowly but surely, are replaced with relations of cooperation and creativity in setting goals, recognizing the importance of integrity, initiative and individual in a group. It became clear that employees do not engage in work activities only to carry out duties and receive a salary, but also to express their skill, knowledge, prove their quality and reaffirm personality. Only if there is sufficient respect, adequate reward and full satisfaction with the status in the organization, the employee will be ready to accomplish his work task to a full extent. Managers must use both organizational and psychological knowledge to build a quality motivational content and combine those motivational techniques that match the specific situation, in order to create a favourable organizational climate and the conditions in which employees can satisfy their own needs and desires, and thus give maximum contribution to the company's success (Popovic, Maletic \& Paunovic, 2017).

The effectiveness of the management concept is reflected in the harmonious functioning of the organization. However, a large number of problems is the result of cultural chaos that is reflected in the general leisure, inconsistent business practices and the lack of business ethics. It adversely affects the efficiency of the organization, leading to the engagement of additional resources, longer working hours, overtime work, which ultimately raises the question of organizational success.

Motivation is the result of the interaction of a person's internal needs and external influences, which determine how a person will behave. With a well-rounded, people-centred philosophy, a manager is ready to motivate by creating a positive, supportive work environment (Robbins, 1989). Motivation is usually defined as the process of activating, directing and maintaining human behaviour toward a specific goal (Ivancevich, Konopaske \& Matteson, 2005). Goals initiate human activity in a certain direction and keep it there until the 
goal gets fulfilled. There are a number of motivation theories, explaining what motivates employees, and how it motivates them in the management literature. Basically, motivation theories can be divided into: content and process theories. Content theories are aimed at discovering the needs and motives that drive to a certain behaviour, trying to provide an answer to the question: what drives human activity? In practice, these theories stipulate that if one manages to discover the answer to the question how to stimulate people to act, he is on the right path to motivate them to make additional efforts. So far, the economic literature has allocated several theories: Maslow's hierarchy of needs, Alfredfer's ERG model, McCllelandova theory of needs and Hertzberg theory of two factors. Maslow (Maslow) finds that people in the organization are motivated by five groups of needs that are hierarchically arranged: physiological, safety needs, social belonging, esteem, and self-actualization. Alderfer's ERG model does not have any assumptions about the hierarchical relationship of human needs. Alfred only claims that people in organizations are motivated by three types of needs: Existence (Maslow correspond to basic needs), Relatedness (the same as the needs of connection and love) and Growth (related to the desire for people to develop, to learn new things, improve their abilities, do interesting and challenging jobs and achieve results).

The Hertzberg theory of motivation is a dual-factor theory consisting of two groups of factors: hygiene and motivation. Hygienic factors (wages, working conditions, business policies, and relationships with management) are the ones that determine the level of dissatisfaction, while the motivational factors (possibility of promotion, prizes and awards) determine the level of satisfaction. McClelland differentiates three kinds of different needs that people need to satisfy in their organizations: the need to affiliate (corresponding to those needs that have been identified with other needs motivation), needs for achievement (a need to achieve job success) and the needs for power or influence to other people.

Contrary to theories of content, process theories are trying to reveal the process by which a person is motivated to undertake certain activities. These theories seek to answer the question of how to run human behaviour? The most important theories include goal-setting theory, the theory of equality and expecting. The basic idea of this theory is that goal setting is a mechanism of motivation because it puts one in a position to compare their skills with those needed for achieving the goal. Intrinsic motivation refers to doing something for its own sake, such as interest or enjoyment, whereas extrinsic motivation refers to doing something for instrumental reasons. These motivations fall in a continuum, ranging from acts done for the pleasure of it (intrinsic) to acts done to gain rewards or to avoid punishment (extrinsic). Importantly, a persons' motivation for a task can be changed. Situations that are perceived as more controlling (for example, because of deadlines, external rewards, or potential punishments) may reduce intrinsic motivation and lead to a more extrinsic orientation (Nix et al., 1999).

According to the theory of equality or fairness, motivation of employees is not influenced only by the efforts/awards trade-off, but also by the comparison of their own effort/rewards to the efforts/rewards of others in the organization. It is obvious that the motivation of employees is not influenced by the actual reward, but the perception of fairness and rewards which in turn arises from its similarity to the other rewards. The theory of expectations is based on the assumption that the behaviour of the employees can be explained by their free choice. The motivation is observed as a cognitive process in which the individual rationally and freely decides whether and what behaviour to take, depending upon its assessment of the effects of such behaviour.

There is a vast literature explaining job satisfaction in banking institutions. Usually these studies connect job satisfaction with other dimensions of human resource management. Job satisfaction is generally understood as an attitude towards one's job. It simply indicates one's contentment with the job. The most widely accepted meaning in literature, according to Cranny et al. (1992) is the degree to which one enjoys doing his /her job (Cranny et al., 1992). Early research on job satisfaction suggested that a productive working environment promotes specific organizational culture and increases employees' job satisfaction (Schneider \& Snyder, 1975). Another study suggests that the measurement of individual dimensions of job satisfaction enables researchers to identify factors related to certain dimensions of job satisfaction (McCormick \& Ilgen, 1987). Some authors maintain that job satisfaction is basically an evaluation of organizational culture (Hutcheson, 1996). According to Durai (2010), performance evaluation seeks to achieve variety of objectives including: defining the performance gaps, identifying employees who deserve promotion, transfer or termination, defining compensation and incentives plan, improving employees' effectiveness and enhancing employees' relationship with the management. Others claim that satisfaction is the only way you can ensure a stable high level of creativity and productivity of employees (Oldham \& Cummings, 1996). The aim of motivation is to transform desire into concrete action, undertake activities that lead to the revitalization of motivation (National Employment Service, 2015). Organizational culture is a good motivator. 
Some recent research shows that employees of different sectors of the bank had different levels of job satisfaction and job-related stress (George, 2015). Some other factors such as internal marketing can have highly significant positive effects on job satisfaction and employee commitment to the bank (Bailey, Albassami \& Al-Meshal, 2016). In addition, authors claim that internal marketing also impacts employee identification with the bank indirectly through its impact on both job satisfaction and employee commitment. A study conducted on the sample of a Greek bank confirms findings according to which role conflict is negatively correlated with job satisfaction (Belias et al., 2015a). In addition, findings suggest that the results from the study should be taken into serious consideration by superiors and managers. Another research on Greek bank employees has found a significant difference between all aspects of organizational culture types among employees of Greek banking institutions. The majority of employees would prefer to work in a more friendly environment, where mutual trust and informal relationships among colleagues are dominant, personal ambitions are taken into consideration and teamwork is rewarded (Belias et al., 2015b). The research based on a survey conducted in Canara identified factors including salary of employees, performance appraisal system, promotional strategies, employee's relationship with management and other co- employees, training and development program, work burden and working hours as the most important for improving job satisfaction of bank employees (Chowdhary, 2013). Jeet and Sayeeduzzafar (2014) examined the impact of human resource management practices on job satisfaction of the private sector banking employees. (Jeet \& Sayeeduzzafar, 2014). Sehgal (2012) studied job satisfaction in banking employees in Shimla as the capital and largest city in Northern India. In this study job satisfaction between private and public banks is compared. Also it is explained that it is important to manage human resources effectively to reach an acceptable job satisfaction and have a success banking as a result. Bowra and Nasir (2014) explored the impact of fairness of performance appraisal on employee motivation and job satisfaction and the endeavours to influence the banking sector in Pakistan. In their published work Panghal and Bhambu (2013) conclude that job satisfaction is closely related to the nature of work, the quality of management, supervisor behaviour, coworker behaviour, pay, promotion, organizational aspects, and working environment. The research analyzing the banking sector outreach in Serbia showed that investments in the development of the distribution network, standardization of procedures and changes in working time, precede the development of those quality elements that predominantly depend on the level of competence and motivation of the staff. Banks appear to have given priority to building quality services that have a more direct effect on profitability (Marinkovic \& Ljumovic, 2010).

During the crisis period, motivation should be developed as moments of positive thinking, as an instrument to reward success and learn from failure. The top management plays a key role in fostering motivation and coping with unmotivated employers. Behaviour based on mutual exchange of ideas between management and employees promotes continuous improvement of these relations invigorating them and creating reciprocal value: attitudes based on trust that include other employees as well as measuring the level of employee satisfaction and identifying areas that need improvement. In transition countries including Serbia, where highly educated staff are faced with poverty and unemployment, financial institutions expect their employees to suppress or subordinate private life to the bank. This new trend is increasingly breaching on privacy and in turn offers a number of privileges.

\section{Research Methodology}

The study has incorporated a descriptive analytical approach to detect the impact of the effectiveness of HRM practices on employees' satisfaction. The data have been collected from various secondary sources such as books, articles, dissertations, journals, the Internet and periodic reports issued by the Serbian banking sector. Primary Data was obtained through a questionnaire related to the variables. The research and measurement of motivation and employee satisfaction can be carried out according to different methodologies. It is possible to use direct methods, indirect methods and combinations of these two. Indirect methods, such as the circulation of staff, interest in training, comparison of salaries, increase in earnings in a given period, operating results, improved working conditions, proposals for improving the system and similar methods can be used but their reliability is extremely limited. Direct methods (questionnaires and interviews) bring a lager quantity of information for drawing conclusions, but also there are limitations that should be taken into consideration. If the survey is anonymous, it is very difficult to assign the results to certain categories of employees that should be the focus of various measures of motivation. On the other hand, a public survey raises the question of sincerity and openness of respondents. When choosing the methodology to analyse motivation and employee satisfaction, the management needs to adjust the method in order to decrease negative effects to the lowest level. 
Employee motivation varies among and is influenced by different factors. Human resource management, as the management of the most important resources of an organization, is a very complex and multi-dimensional process (Piderit, 2000). If an employee satisfies one need, other needs emerge and have to be satisfied. Investment in human resource activities has a significant impact on the effectiveness of investment in human capital in commercial banks in Jordan. Moreover, the study findings showed a significant impact of staffing, training \& development, incentives and retention policy on the effectiveness of investment in human capital. On the other hand, training \& development and employee incentives systems have a direct impact on the human capital return on investment and human capital added value. Investing in human capital is one of the factors that have a direct impact on minimizing the turnover rate, through preparing and implementing a retention policy to focus on building professional loyalty among employees (Al-Ghazawi, 2012). The training and development are the continuous efforts aimed to improve employee capability and organizational performance by providing employees with the required knowledge and skills to perform their jobs (Mondy \& Mondy, 2014). However, common factors that influence most of the employees are the amount of salary, interest in the job, the likelihood of career promotion, degree of independence, the opportunity for personal affirmation. These factors depend on the qualifications, expertise and personal preferences of each employee. Based on various biophysical, psychological and social factors, there is a need to explore pull factors for better performance and effects. This is a preventive measure, since employees tend to express their desires and needs rather than to express their dissatisfaction. Based on literature review and the paper from Kruger and his associates (Kruger at al., 2008) we have developed the following hypotheses:

H1: Employees "are satisfied" with the process of selection in employee recruiting;

H2: Employees "are satisfied" with salaries and other income;

H3: Employees "are satisfied" with job security;

H4: Employees "are satisfied" with career advancement;

H5: Employees "are satisfied" with professional training and development;

H6: Employees "are satisfied" with the management style;

H7: Employees "are satisfied" with responsibility at work;

H8: Employees "are satisfied" with the rewards and motivation;

H9: Employees "are satisfied" with the business climate.

The purpose of this statistical analysis is to reject the null hypothesis (two tailed test). In this research, this methodology is useful, because it allows us to accept the results of the hypotheses made on a sample of employees from 10 banks.

Having in mind the defined hypotheses, identified constrains and literature review, we have structured questionnaires. The target population were employed in the banking sector in Serbia. In order to ensure a reliability of the collected data, we used a personal approach to 100 employees in ten chosen banks. A direct contact with them assured a high respondent rate and none of the employees refused to participate in the study. Out of 100 questionnaires 93 were correctly filled and were available for statistical analysis. Questions included in the questionnaire were stipulated in a way that allows further processing and statistical analysis.

The questionnaire consisted of two parts. The first part of the questionnaire contained questions that were used to test the employees' work satisfaction and to identify possible problems regarding motivation. There were nine different types of questions designed to test the process of recruiting and selection of employees, job security, salaries, career advancement, professional training and development, management style, job responsibility, rewards and recognition and business climate. In order to determine the degrees of agreement with the statement given in the questionnaire, we used a five-level Likert scale $(1$ = very dissatisfied, $2=$ largely not satisfied, $3=$ undecided $4=$ partly satisfied; $5=$ very satisfied). Each question in the questionnaire was given together with a concise explanation, in order to eliminate possible errors and ambiguities of the respondents. In the second part of the questionnaire, respondents gave answers to the questions that determined their basic characteristics and identity: gender, age, level of education and years of experience. Table 1 shows the distribution of basic characteristics of the sample. Data suggest that the banking sector is dominated by women, middle-aged employees, aged between 29 and 39, with high education and over 10 years of experience. 


\begin{tabular}{|l|l|r|r|}
\hline \multicolumn{1}{|c|}{ Question } & \multicolumn{1}{|c|}{ Answer } & Frequency & Percent \\
\hline \multirow{2}{*}{ Gender } & Women & 64 & $69 \%$ \\
\cline { 2 - 4 } & Men & 29 & $31 \%$ \\
\hline \multirow{4}{*}{ Age } & $19-28$ & 32 & $34 \%$ \\
\cline { 2 - 4 } & $29-39$ & 35 & $38 \%$ \\
\cline { 2 - 5 } & $40-50$ & 19 & $20 \%$ \\
\cline { 2 - 5 } & Over 50 & 7 & $8 \%$ \\
\hline \multirow{2}{*}{ Education level } & Higher education including MSc and PhD & 76 & $82 \%$ \\
\cline { 2 - 5 } & Secondary education & 17 & $18 \%$ \\
\hline \multirow{4}{*}{ Years of experience } & $1-5$ & 10 & $11 \%$ \\
\cline { 2 - 5 } & $5-10$ & 35 & $38 \%$ \\
\cline { 2 - 5 } & $10-20$ & 30 & $32 \%$ \\
\cline { 2 - 5 } & Over 20 & 18 & $19 \%$ \\
\hline
\end{tabular}

Table 1: Frequencies of the basic characteristics of the sample Source: Authors' own calculation based on the survey

\section{Results and Discussion}

"Job satisfaction" represents the extent to which individuals are satisfied with their job and love it. Many organizations determine job satisfaction levels of their employees from their attitude. Motivation and Job Satisfaction are not synonymous with each other. Namely, Motivation and Job Satisfaction are sharing similar dependant variables but they will not guarantee the same impact on organizational behaviours. Job Satisfaction is an emotional response that will results in broad behavioural actions towards working environment, while Motivation is a behavioural action that may return with specific emotional response.

Numerical values obtained by the survey were statistically processed and for each variable (question) the mean value and standard deviation were calculated. Values are given in Table 2 . The statistical characteristics of the variability of the collected responses indicate the uniformity of the answers to the questions asked. The variation interval, which represents the difference between maximum and minimum value, is relatively low (0.68) with acceptable values of standard deviation. According to the data from Table 2, the greatest satisfaction is found in the dimension related to the Career advancement, $52.39 \%$, and Job security, $52 \%$. At the same time these are the only dimensions that exceed $50 \%$ of the level of satisfaction. They are followed by Professional training and development with $45.22 \%$, Job responsibility and System of awarding share the same percent, $38.97 \%$ each. The process of recruiting and selection of employees account for $38.59 \%$, Management style of bank accounts for $37.07 \%$, Business climate $33 \%$ and finally, employees are least satisfied with earnings, $28.43 \%$. Further processing required analyses of each question separately.

\begin{tabular}{|l|l|c|c|c|c|c|c|}
\hline No & & $\mathbf{N}$ & Mean & $\begin{array}{c}\text { Std. } \\
\text { Deviation }\end{array}$ & $\begin{array}{c}\text { Std. Error } \\
\text { Mean }\end{array}$ & $\begin{array}{c}\text { Z-score } \\
\text { computation } \\
\text { of Z value }\end{array}$ & Probability \\
\hline 1 & $\begin{array}{l}\text { The process of recruiting } \\
\text { and selection of } \\
\text { employees }\end{array}$ & 93 & 2.97 & 1.026 & 0.106 & 0.29 & $\mathrm{P}(\mathrm{X}<3)=\mathrm{P}(\mathrm{Z}<0.29)=0.61409$ \\
\hline 2 & Job security & 93 & 3.06 & 1.258 & 0.130 & -0.05 & $\mathrm{P}(\mathrm{X}<3)=\mathrm{P}(\mathrm{Z}<(-0,05))=0.48006$ \\
\hline 3 & Salaries & 93 & 2.40 & 1.044 & 0.108 & 0.57 & $\mathrm{P}(\mathrm{X}<3)=\mathrm{P}(\mathrm{Z}<0.57)=0.71566$ \\
\hline 4 & Career advancement & 93 & 3.08 & 1.361 & 0.141 & -0.06 & $\mathrm{P}(\mathrm{X}<3)=\mathrm{P}(\mathrm{Z}<(-0.06))=0.47608$ \\
\hline 5 & $\begin{array}{l}\text { Professional training and } \\
\text { development }\end{array}$ & 93 & 2.83 & 1.348 & 0.140 & 0.12 & $\mathrm{P}(\mathrm{X}<3)=\mathrm{P}(\mathrm{Z}<0.12)=0.54776$ \\
\hline 6 & Management style & 93 & 2.54 & 1.411 & 0.146 & 0.33 & $\mathrm{P}(\mathrm{X}<3)=\mathrm{P}(\mathrm{Z}<0.33)=0.62930$ \\
\hline 7 & Responsibility at work & 93 & 2.60 & 1.408 & 0.146 & 0.28 & $\mathrm{P}(\mathrm{X}<3)=\mathrm{P}(\mathrm{Z}<0.28)=0.61026$ \\
\hline 8 & Awards and recognition & 93 & 2.70 & 1.061 & 0.110 & 0.28 & $\mathrm{P}(\mathrm{X}<3)=\mathrm{P}(\mathrm{Z}<0.29)=0.61026$ \\
\hline 9 & Business climate & 93 & 2.45 & 1.256 & 0.130 & 0.44 & $\mathrm{P}(\mathrm{X}<3)=\mathrm{P}(\mathrm{Z}<0.44)=0.67003$ \\
\hline
\end{tabular}

Table 2: Aspects of employee satisfaction

Source: Authors' calculation based on the survey

H1: Employees "are satisfied" with the process of selection in employee recruiting.

The assumption for this hypothesis is that employees are satisfied with the process of selection of employees and recruiting. The hypothesis is accepted and therefore we can conclude that employees in the banking sector are satisfied with the selection and recruiting of employees (Figure 2). However, $61.41 \%$ (57 out of all employees that participated in the research) of respondents are not satisfied with this dimension of motivation and rated it lower than 3 . More than $38 \%$ of employees have higher satisfaction than average. 


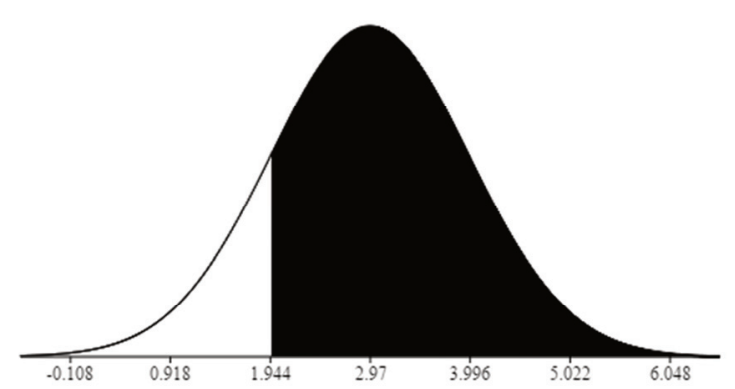

Figure 2: Distribution of the "The process of recruiting and selection of employees" dimension

H2: Employees "are satisfied" with job security.

The assumption for this hypothesis is that employees are satisfied with job security. The hypothesis is accepted and we can conclude that employees in the banking sector are satisfied with job security. Higher satisfaction than average was reported by $52 \%$ of respondents (Figure 3 ). $48 \%$ (45 out of all employees that participated in the research) of respondents rated this dimension lower than three points.

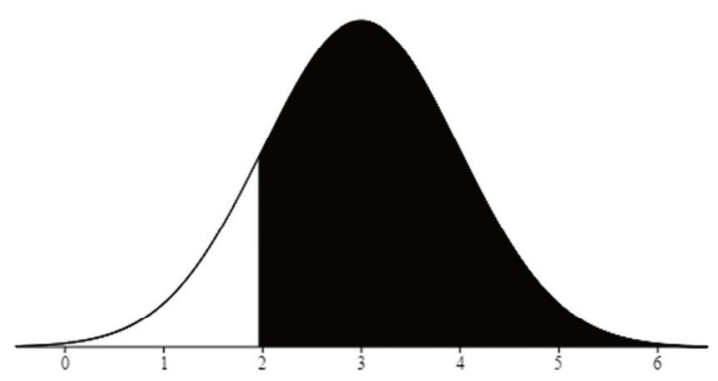

Figure 3: Distribution of the "Job security" dimension

H3: Employees "are satisfied" with salaries.

The answer for the question whether employees are satisfied with the salaries is positive, because $28.43 \%$ of employees reported higher satisfaction than average. The assumption of this hypothesis is that employees are satisfied with their salaries. The hypothesis is accepted and therefore we can conclude that employees are satisfied with the salaries and other earnings in the banking sector. Higher satisfaction than average was reported by $28.43 \%$ (67 out of all employees that participated in the research) respondents (Figure 4). However, $71.57 \%$ of employees are not satisfied with their earnings.

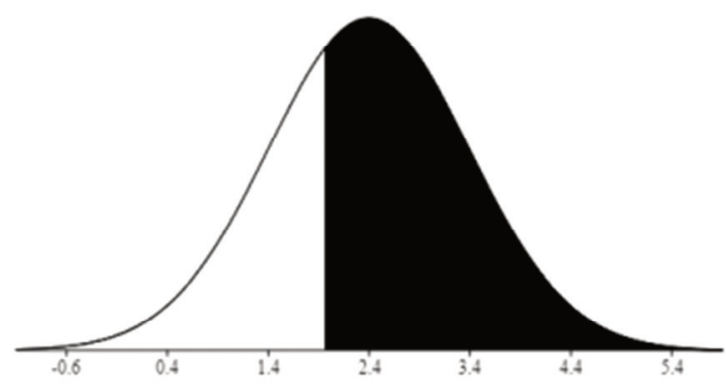

Figure 4: Distribution of the "Salaries" dimension

H4: Employees "are satisfied" with career advancement.

The assumption for this hypothesis is that employees are satisfied with their career advancement. The hypothesis is accepted and we can conclude that employees are satisfied with the career advancement in the banking sector. However, $47.60 \%$ (44 out of all employees that participated in the research) of respondents are not satisfied with this dimension of motivation and rated it lower than 3 . Higher satisfaction than average was reported by $52.39 \%$ of employees (Figure 5). 


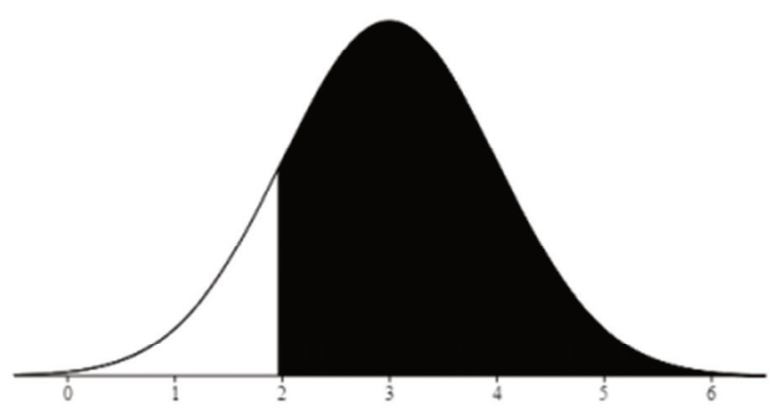

Figure 5: Distribution of the "Career advancement" dimension

H5: Employees "are satisfied" with the professional training and development.

The assumption for this hypothesis is that employees are satisfied with the professional training and development. The hypothesis is accepted and we can conclude that employees are satisfied with the professional training and development in the banking sector. However, 54.78\% (51 out of all employees that participated in the research) of respondents are not satisfied with this dimension of motivation and rated it lower than 3. Higher satisfaction than average was reported by $52.39 \%$ of employees (Figure 6 ).

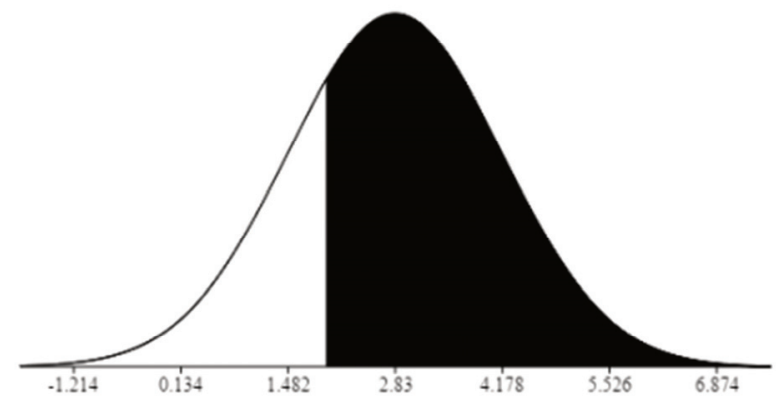

Figure 6: Distribution of the "Professional training and development" dimension

H6: Employees "are satisfied" with the management style.

The assumption for this hypothesis is that employees are satisfied with the professional management style. The hypothesis is accepted and we can conclude that employees are satisfied with the professional management style in the banking sector. However, 62.93\% (58 out of all employees that participated in the research) of respondents are not satisfied with this dimension of motivation and rated it lower than 3 . Higher satisfaction than average was reported by $37.07 \%$ of employees (Figure 7 ).

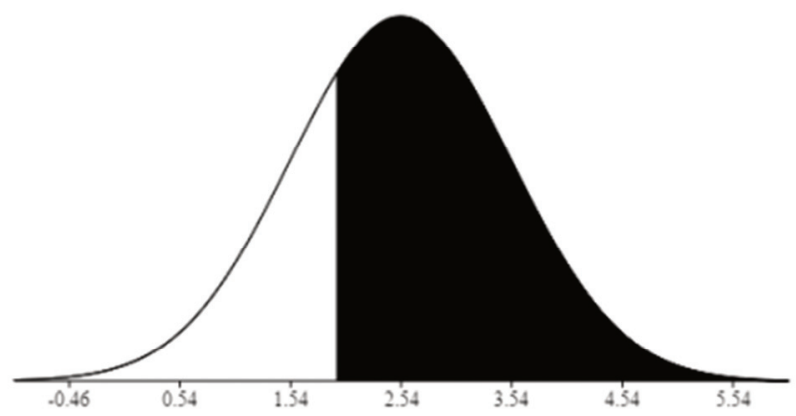

Figure 7: Distribution of the "Management style" dimension

H7: Employees "are satisfied" with responsibility at work.

The assumption for this hypothesis is that employees are satisfied with teamwork and assigned responsibilities. The hypothesis is accepted and we can conclude that the employees are satisfied with teamwork and assigned responsibilities in the banking sector. However, 61.03\% (57 out of all employees that participated in the research) of respondents are not satisfied with this dimension of motivation and rated it lower than 3. Higher satisfaction than average was reported by $38.97 \%$ of employees (Figure 8). 


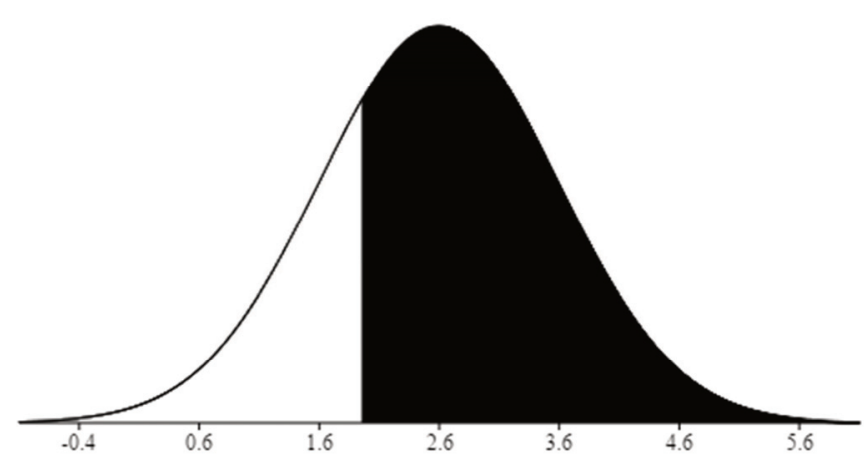

Figure 8: Distribution of the "Teamwork and given responsibilities" dimension

H8: Employees "are satisfied" with the rewards and motivation.

The assumption for this hypothesis is that employees are satisfied with the system of awarding. The results for this dimension are the same as in the previous one. The hypothesis is accepted and we can conclude that the employees are satisfied with the system of awarding in the banking sector. However, $61.03 \%$ (57 out of all employees that participated in the research) of respondents are not satisfied with this dimension of motivation and rated it lower than 3. Higher satisfaction than average was reported by $38.97 \%$ of employees (Figure 9).

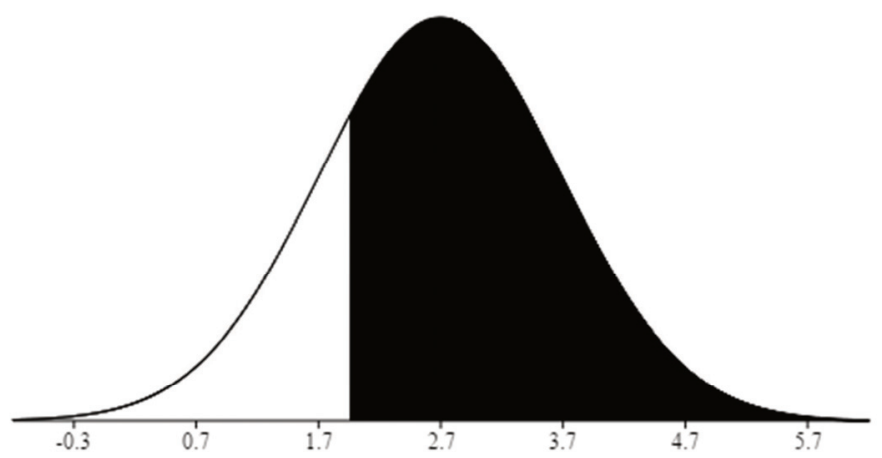

Figure 9: Distribution of the "System of awarding" dimension

H9: Employees "are satisfied" with the business climate.

The assumption for this hypothesis is that employees are satisfied with the business climate. The hypothesis is accepted and we can conclude that employees are satisfied with the business climate in the banking sector. However, 67\% (62 out of all employees that participated in the research) of respondents are not satisfied with this dimension of motivation and rated it lower than 3 . Higher satisfaction than average was reported by $33 \%$ of employees (Figure 10).

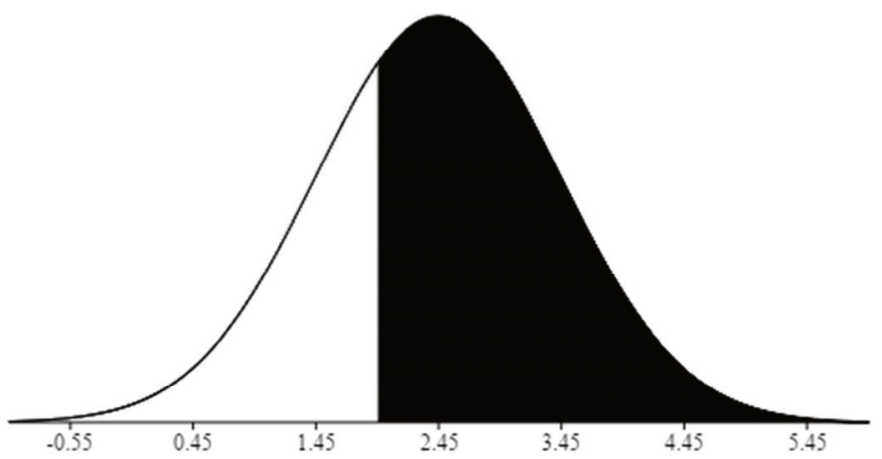

Figure 10: Distribution of the "Business climate" dimension 
Conslusion

The study only includes Serbia as a population area, while future studies should attempt at a comparative analysis by undertaking Middle Eastern countries to provide differences between their HRM practices. All indicators of the Serbian banking sector, including employment, have developed and have had growth since 2000 . However the consequences of global financial crisis manifested in Serbia too. Although some other indicators, such as total assets or credit activity did not decrease or had a minor decrease over the years after the crisis, the number of employees in the banking sector decreased to a larger extent. Having this in mind it is extremely important to analyse the current status of employee satisfaction. Using a nine key factor model that represents the basis of human resource management, we analysed employees' satisfaction in the banking sector in Serbia. Analysing the respondents' replies from the survey we found that the results were mixed and all employees in banks were not equally satisfied. In some aspects (Career advancement and Job security), the respondents show a higher level of satisfaction. In other aspects of satisfaction, such as Salaries and Business Climate, the dimensions were rated showing a much lower satisfaction. Table 2 shows the different levels of employee satisfaction in the banking institutions. The data show that employees are not fully satisfied with all analysed dimensions of employee motivation in banking institutions. The best rated dimensions are Career advancement and Job security, while the respondents are least satisfied with Salaries and Business Climate.

However, the results obtained by the model we used indicate that the banks operating in Serbia need to review their policies towards motivating employees and to create them based on clear, realistic and understandable framework. They should put focus on both the financial and non-financial benefits that employees can utilize, which can in turn lead to an increase in their satisfaction. Compensation systems are necessary that recognize and encourage individual and team performance, satisfying internal customer needs and requirements, by applying adequate and equitable payments (Khasawneh \& Mdanat, 2018). The prioritization of the system for human resource management should start from the financial motivation of employees, improving the business climate, changes in the management style, adequate process of selection and recruiting of employees, job responsibility and system of awards. A good team of bank employees need support from their management and need to be motivated in various ways. To be more specific, correct incentive mechanisms include adequate earnings and other benefits. Transparency and the open and efficient system of remuneration, benefits and salaries is very desirable. It is possible to create business climate by respecting individuals and thus build confidence among employees and loyalty to the institution. Protectionism, abuse and discrimination of employees should always be prevented. The importance of this study is in that it highlighted the effectiveness of a crucial, fundamental HRM function, that is compensation. However, banks' management may show concern for both financial and non-financial compensation as financial compensation seems to have an increasing impact on employees' satisfaction. Consequently, it is indispensable for Jordan's banks to consider and engage in a process of redesigning and reengineering their pay systems along with financial compensations in other fast-growing sectors.

Although the present study was confined to identify the impact of HR practises on job satisfaction, it may be appropriate to state briefly the policy implications for the study. In this context, the following policy actions may be considered worthwhile: organizations should offer extensive training and development programmes for the employees, organizations should go for thorough HR planning, organizations should offer at least reasonable compensation to the employees, organizations should develop good working conditions, organizations should induce employees to perform well, organizations should implement equal employment opportunities, organizations should design work procedures including work hours, over time payment and hourly payment, proper working environment should be designed, organizations should design good grievance procedure, disciplinary procedure and separation procedure etc. This can be achieved by providing reward, motivations, and other benefits etc. (Absar et al., 2010). Since the majority of banks in Serbia are part of international banking groups, they should also follow the example of their host institutions. Although financial motivation is effective, other various techniques and activities could be used to strengthen team spirit, because the collective is the main driver of positive and negative motivation. There is a fine line between what people see as the support and motivation, or as an offer to limit their private lives.

Small sample size was one of the major limitations of the present study. The study did not cover all the HR practices of the surveyed banking firms. Additionally, the research model of this study can be retested in business organizations, so that the research model can be generalized to other economic sectors. 


\section{REFERENCES}

[1] Absar, M., Azim, M., Balasundaram, N., \& Akhter, S. (2010). Impact of Human Resources Practices on Job Satisfaction: Evidence from Manufacturing Firms in Bangladesh. Economic Science Series, Petroleum-Gas University of Ploiesti Bulletin. LXII. 1-82.

[2] Al-Ghazawi, M. (2012). The impact of investments in human resources activities on the effectiveness of investment in human capital: The case of commercial banks in Jordan. International Journal of Business and Social Science, 3(18), 253-261. DOI: 10.30845/ijbss

[3] Bailey, A. A., Albassami, F., \& Al-Meshal, S. (2016). The roles of employee job satisfaction and organizational commitment in the internal marketing-employee bank identification relationship. International Journal of Bank Marketing, 34(6), 821-840. DOI: 10.1108/IJBM-06-2015-0097

[4] Beck, Th., \& Peria, M. M. (2010). Foreign bank participation and outreach: Evidence from Mexico. Journal of Financial Intermediation, 19(1), 52-73.DOI:10.1016/j.jfi.2009.03.002

[5] Belias, D., Koustelios, A., Sdrolias, L., \& Aspridis, G. (2015a). Job satisfaction, role conflict and autonomy of employees in the Greek banking organization. Procedia-Social and Behavioral Sciences, 175, 324-333. DOI: 10.1016/j.sbspro.2015.01.1207

[6] Belias, D., Koustelios, A., Vairaktarakis, G., \& Sdrolias, L. (2015b). Organizational culture and job satisfaction of Greek banking institutions. Procedia-Social and Behavioral Sciences, 175, 314-323. DOI: 10.1016/j.sbspro.2015.01.1206.

[7] Bowra, Z. A., \& Nasir, A. (2014). Impact of Fairness of Performance Appraisal on Motivation and Job Satisfaction in Banking Sector of Pakistan. Journal of Basic and Applied Scientific Research, 4(2), 16-20.

[8] Chowdhary, B. (2013). Job satisfaction among bank employees: An analysis of the contributing variables towards job satisfaction. International journal of scientific \& technology research, 2(8), 11-20. Retrieved from: http://www.ijstr.org/final-print/aug2013/Job-Satisfaction-Among-Bank-Employees-AnAnalysis-Of-The-Contributing-Variables-Towards-Job-Satisfaction.pdf

[9] Claessens, S., \& van Horen, N. (2008). Location decision of foreign banks and competitive advantage (World Bank Policy Research Working Papers No. 4113). Washington, DC: World Bank. Retrieved from: https://onlinelibrary.wiley.com/doi/abs/10.1111/jmcb.12100

[10] Cranny, C. J., Smith, P. C., \& Stone, E. F. (1992). Job satisfaction: how people feel about their jobs and how it affects their performance. New York: Lexington Books.

[11] Debreu G. (1954). Valuation equilibrium and Pareto optimum. Proceedings of the National Academy of Sciences of the United States of America, 40(7), 588-92.

[12] Degryse, H., Havrylchyk, O., Jurzyk, E., \& Kozak, S. (2012). Foreign bank entry, credit allocation and lending rates in emerging markets: Empirical evidence from Poland. Journal of Banking \& Finance, 36(11), 2949-2959. DOI:10.1016/j.jbankfin.2011.12.006

[13] Detragiache, E., Tressel, T., \& Gupta, P. (2008). Foreign banks in poor countries: theory and evidence. The Journal of Finance, 63(5), 2123-2160. Retrieved from: https://www.imf.org/external/np/res/seminars/2006/arc/pdf/tressel.pdf

[14] Durai, P. (2010). Human Resources Management. India: Dorling Kindersley.

[15] George, E. (2015). Job related stress and job satisfaction: a comparative study among bank employees.Journal of Management Development, 34(3), 316-329.

[16] Hutcheson, S. (1996). The development of a measure of organizational climate. Unpublished Master Thesis, University of Witwatersrand, Johannesburg.

[17] Ivancevich, J. M., Konopaske, R., \& Matteson, M. T. (2005). Organizational behavior and management (7th ed.). Boston: McGraw-Hill Irwin.

[18] Jeet \& Sayeeduzzafar (2014). A Study of HRM Practices and its Impact on Employees job Satisfaction in Private Sector Banks: A Case Study of HDFC Bank. International Journal of Advance Research in Computer Science and Management Studies, 2(1), 62-68.

[19] Kanter, R.M. (2011). How Great Companies Think Differently. Harvard Business Review 89 (11) Retrieved from: https://hbr.org/2011/11/how-great-companies-think-differently.

[20] Khasawneh, A. \& Mdanat, H. (2018). Level of Effectiveness of Human Resource Management Practices and Its Impact on Employees' Satisfaction in the Banking Sector of Jordan. Journal of Organizational Culture, Communications and Conflict. 22 (1), 1-19.

[21] Kilenthong, W. T., \& Townsend, R. M. (2011). Information-Constrained Optima with Retrading: An Externality and Its Market-Based Solution. Journal of Economic Theory, 146(3), 1042-1077. DOI: 10.1016/j.jet.2010.11.001

[22] Kruger, J., Windschitl, P. D., Burrus, J., Fessel, F., \& Chambers, J. R. (2008). The rational side of egocentrism in social comparisons. Journal of Experimental Social Psychology, 44(2).

DOI:10.1016/j.jesp.2007.04.001 
[23] Marinkovic, S., \& Ljumovic, I. (2010). Quality of services and the degree of outreach in Serbian banking industry: Some social aspects. Ekonomika preduzeca, 58(3-4), 149-159.

[24] Marinkovic, S., Ljumovic, I., \& Zivkovic, A. (2011). Strane direktne investicije u bankarstvu Republike Srbije: istraživanje motiva. Međunarodni problemi, 63(4), 505-535. DOI:10.2298/MEDJP1104505M

[25] McCormick, E.T. \& Ilgen, D. (1987). Industrial and Organizational Psychology. (8th Ed.) London: Routledge.

[26] Mondy, R.W \& Mondy, J.B. (2014). Human resource management (13th Edition). Global Edition, Pearson education Limited, Courier/Kendallville, United State of America.

[27] National Employment Service, 2015, Retrieved from http://www.nsz.gov.rs/

[28] Nix, A.G., Ryan, M.R., Manly, B. J. \& Deci, L.E. (1999). Revitalization through Self-Regulation: The Effects of Autonomous and Controlled Motivation on Happiness and Vitality, Journal of Experimental Social Psychology 35(3), 266-284.

[29] Oldham, G. R., \& Cummings, A. (1996). Employee creativity: Personal and contextual factors at work. Academy of management journal, 39(3), 607-634. DOI:10.2307/256657

[30] Panghal, S. \& Bhambu, S. (2013). Factors influencing job satisfaction of banking sector employees in India. International Journal of New Innovations in Engineering and Technology, 1(3), 41-44.

[31] Piderit, S. K. (2000). Rethinking resistance and recognizing ambivalence: A multidimensional view of attitudes toward an organizational change. Academy of management review, 25(4), 783-794. Retrieved from: https://goal-lab.psych.umn.edu/orgpsych/readings/18.../Piderit\%20(2000).pdf

[32] Popovic, B., Maletic, R., \& Paunovic, T. (2015). Employee Satisfaction Survey in Function of Business Improvement. Management:Journal Of Sustainable Business And Management Solutions In Emerging Economies, 20(76), 31-40. DOI:10.7595/management.fon.2015.0021

[33] Robbins, Stephen P. (1989). Organizational behavior: concepts, controversies, and applications (4 th ed). Prentice Hall, Englewood Cliffs, N.J

[34] Schneider, B \& Snyder, R.A. (1975). Some relationship between job satisfaction and organizational climate. Journal of Applied Psychology, 60(3), 318-328. Retrieved from: DOI:10.1037/h0076756

[35] Sehgal, S. (2012). Job Satisfaction of Bank Employees in Shimla- A Comparative Study of Private and Public Sector Bank (Axis Bank and UCO Bank). International Journal of Marketing, Financial Services and Management Research, 1(7), 124-146.

Received: 2018-06-21

Revisions requested: 2018-10-18

Revised: 2018-11-26

Accepted: 2018-12-18

\section{$1 / 1 / 1 / 1 / 1 / 1 / 1 / 1 / 1 / 1 / 1 / 1 / 1 / 1 / 1 /$ abouthe authors}

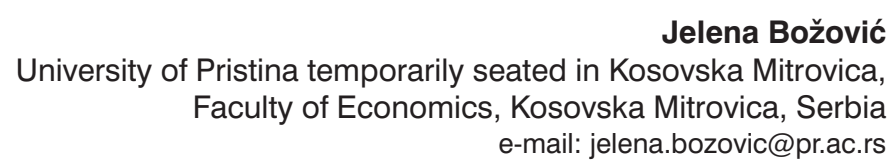

Jelena Božović, $\mathrm{PhD}$, is a full Professor at the University of Priština with a temporary seat in Kosovska Mitrovica, Faculty of Economics. She earned her Masters and Doctoral degrees in the field of banking. She has actively participated in implementation of several domestic and international projects. She has published three monographs, a workbook, a textbook, a collection of exercise books, questions and answers from banking and a handbook of key insurance terms. She has published numerous scientific papers in domestic and international journals and has participated in domestic and international conferences.

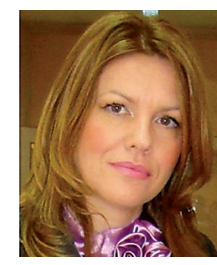


Ivan Božovic

University of Pristina temporarily seated in Kosovska Mitrovica,

Faculty of Economics, Kosovska Mitrovica, Serbia e-mail: ivan.bozovic@pr.ac.rs

Ivan Božović, PhD, is a associate professor at the University of Priština with a temporary seat in Kosovska Mitrovica, Faculty of Economics. He has earned a Masters and Doctoral degrees in the field of macroeconomics. He has actively participated in implementation of domestic projects. He has published a monograph and a workbook

in the field of macroeconomic analysis. He has published several papers in domestic journals and has participated in domestic and international scientific conferences.

Isidora Ljumović Institute of Economic Sciences, Belgrade, Serbia e-mail: Isidora.ljumovi@ien.bg.ac.rs

Isidora Ljumović, PhD is employed as a research associate at the Institute of Economic Sciences in Belgrade. She graduated in the field of organizational sciences, and she got her Masters and PhD degree in the field of banking. She is engaged in several domestic and international projects, among which the projects that are financed by the MESTD

RoS, the World Bank, the European Union ant other international donors. She has published two monographs, numerous scientific papers in domestic and international scientific journals and has participated in a scientific conferences in Serbia and abroad.
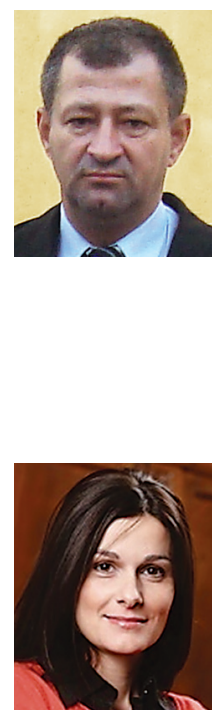